\title{
Propionate Metabolism in Cells Cultured from a Patient with Methylmalonic Acidemia
}

\author{
Grant Morrow III[11], W.J. Mellman, L.A. Barness and N.V.Dimitrov \\ Departments of Pediatrics and Medical Genetics, University of Pennsylvania School of Medicine, \\ and Departments of Medicine and Biochemistry, Hahnemann Medical College, Philadelphia, \\ Pennsylvania, USA
}

\begin{abstract}
Extract
Propionate metabolism in human skin fibroblasts was studied in cells from three controls and one patient with methylmalonic acidemia. In the control cells, propionate-2- ${ }^{14} \mathrm{C}$ was metabolized to succinate and thence into the citric acid cycle, as indicated by the appearance of the $\mathrm{C}$ label in $\mathrm{CO}_{2}$, succinate, aspartate, and glutamate. The patient's fibroblasts accumulated methylmalonate and failed to convert the $\mathrm{C}$ label as readily into $\mathrm{CO}_{2}$, aspartate, and glutamate.
\end{abstract}

\section{Speculation}

Human skin fibroblasts cultured from a patient with methylmalonic acidemia offer an in vitro technique of pinpointing the defective site in this disorder. Furthermore, the kinetic properties of the mutant enzyme can be readily investigated.

\section{Introduction}

Methylmalonic acidemia (MMA-emia) is a genetic disease recently described by OBERholzer et al. [6]. Characteristically, infants with this condition have profound acidosis, lethargy, failure to grow, vomiting, and early death. MMA-emia can be diagnosed by finding excessive amounts of methylmalonate in the urine of a patient without signs of vitamin $\mathrm{B}_{12}$ deficiency.

Methylmalonate is an intermediate in the metabolism of propionate and succinate. White cell preparations from normal individuals readily incorporate the labeled carbon from either propionate- $2{ }^{14} \mathrm{C}$ or $-3-{ }^{14} \mathrm{C}$ into $\mathrm{CO}_{2}$, citric acid cycle intermediates, lactate, aspartate, and glutamate via the Krebs citric acid cycle [7]. Peripheral white cells from patients with MMA-emia fail to metabolize propionate normally $[1,6]$. Evidence shows that propionate metabolism can be studied in fibroblast-like cell lines from human skin biopsies and that these cells provide an effective means of investigating a patient with methylmalonic acidemia.

\section{Materials and Methods}

Cell lines were derived from skin biopsies of four individuals, one a patient with MMA-emia. Methods for the growth and propagation of these cell lines have been previously described [3]. Cells were subcultured and harvested after they had reached confluence and had stopped rapidly dividing. At the time of incubation, the cell sheet was rinsed with a calcium- and magnesiumfree salt solution, trypsinized, and suspended in versene [9]. After centrifugation, the cells were resuspended in Krebs-Ringer bicarbonate, and $2.86 \mu \mathrm{c}$ of propionate$2{ }^{14} \mathrm{C}$ were added. In all experiments, the cells were suspended in $10 \mathrm{ml}$ of Krebs-Ringer bicarbonate at $\mathrm{pH}$ 7.35-7.40 (table I). Incubations were carried out 
at $37^{\circ}$ with gentle shaking. The assay mixtures in experiments 1-3 were incubated for 4 hours in an atmosphere of $5 \% \mathrm{CO}_{2}$ in $\mathrm{O}_{2}$. The mixture in experiment 4 was incubated for 2 hours in $5 \% \mathrm{CO}_{2}$ in air. The reactions were terminated with $1 \mathrm{ml}$ of $35 \%$ perchloric acid, and the $\mathrm{CO}_{2}$ was trapped for one hour in $1 \mathrm{ml}$ of Hyamine ${ }^{\circledR}$ or NCS ${ }^{\circledR}$. Blanks consisted of cells boiled for 10 minutes and incubated under the same conditions. Cell counts and DNA determinations were made on the cell suspensions [9]. The incubation mixture was then centrifuged, and the supernatant was extracted in ether for 48 hours and collected in $\mathrm{NaOH}$. The ether extract was fractionated on a silicic acid column [5]. The amino acids were isolated from the nonextractable portion by passage over Dowex columns as described elsewhere [7]. Nonlabeled aspartate and glutamate were added as carriers and as markers to locate the amino acid positions on descending paper chromatograms. After counting the paper strips, the glutamate and aspartate spots were eluted, and the amino acids recrystallized to constant specific activity.

\section{Results}

Incorporation of ${ }^{14} \mathrm{C}$ from propionate into $\mathrm{CO}_{2}$, aspartate, and glutamate is noted in table 1 . All three control patients readily incorporated the label into these components. In two separate experiments, ${ }^{14} \mathrm{CO}_{2}$ production from patient cells was less than $3.5 \%$ of the simultaneously run control cells. Production of ${ }^{14} \mathrm{CO}_{2}$ by the control cells was linear with respect to total DNA for incubation pericds up to 4 hours. A study of the effect of increasing propionate concentrations upon ${ }^{14} \mathrm{CO}_{2}$ production indicated that the incubation 'system' was saturated, since an increase in propionate above the level chosen gave no increased activity.

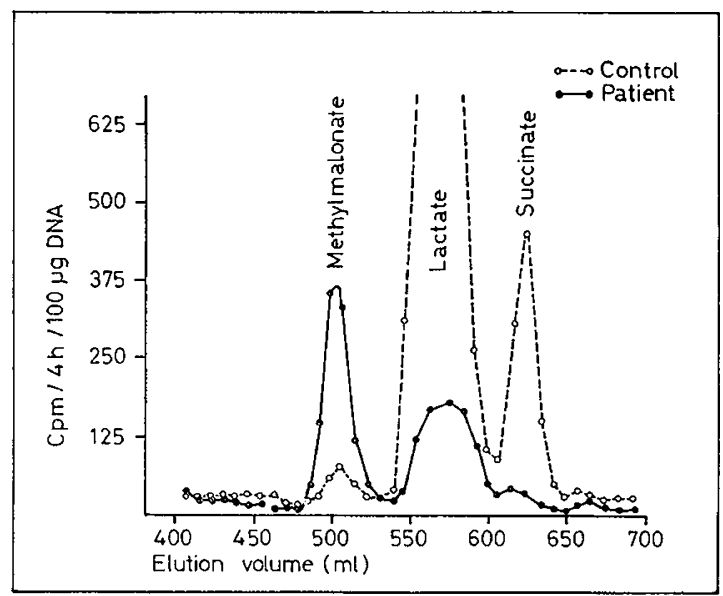

Fig. 1. Portions of radiochromatograms from the extract of cells incubated with ${ }^{14} \mathrm{C}$-propionate in experiment 3 , table I. The organic acids were eluted from a silicic acid column using a gradient elution system of chloroform in tertiary amyl alcohol [5]. The effluent was collected in $\mathrm{N} \mathrm{NaOH}$ and counted with a liquid scintillation spectrometer.

Figure 1 depicts the elution patterns for methylmalonate, lactate, and succinate of the extract from the cells incubated with ${ }^{14} \mathrm{C}$-propionate. The fractions from the control cells contain a large amount of lactate and succinate, in contrast to the patient's pattern, which reveals a large quantity of methylmalonate, a trace of succinate, and only $7 \%$ of the amount of lactate found in the controls. No detectable methylmalonate, i. e., $<5 \mu \mathrm{g} / 16 \times 10^{6}$ fibroblasts, was found in the patient's cells. This fact would rule out enzyme saturation by endogenous substrate as the cause of the accumulation of labeled methylmalonate seen in figure 1 . The re-

Table I. Metabolic conversion of ${ }^{14} \mathrm{C}$-propionate

\begin{tabular}{|c|c|c|c|c|c|}
\hline Experiment & Gells $\times 10^{6}$ & $\begin{array}{l}\text { DNA } \\
\text { mg }\end{array}$ & $\mathrm{CO}_{2}$ & $\begin{array}{c}\text { Aspartate } \\
\mathrm{cpm} / \mathrm{h} / \mathrm{mg} \text { DNA }\end{array}$ & Glutamate \\
\hline 1-Control & 66 & 0.686 & 19,100 & -1 & - \\
\hline 2-Control & 25 & 0.297 & 30,400 & 1,100 & 9,100 \\
\hline 3-Control & 40 & 0.572 & 15,900 & 500 & 3,700 \\
\hline Patient & 33 & 0.564 & 600 & 0 & 0 \\
\hline 4-Control & 16 & 0.249 & 4,200 & - & - \\
\hline Patient & 14 & 0.290 & 90 & - & - \\
\hline
\end{tabular}

1 Not counted.

The reaction mixture contained $72.5 \mu \mathrm{g}(2.86 \mu \mathrm{c})$ of propionate $-2 .{ }^{14} \mathrm{C}$ in a total volume of $10 \mathrm{ml}$. Less than $5 \%$ of the original substrate was utilized during the incubation. 
mainder of the effluent, when reextracted with ether and subjected to two dimensional chromatography on paper [2], confirmed the identification of the compounds in the original radiochromatograms.

\section{Discussion}

Propionate metabolism has been extensively studied in tissues [4] other than human diploid skin fibroblast cells. Propionate is readily converted to propionyl CoA, then to methylmalonyl CoA, and enters the Krebs citric acid cycle through succinyl CoA. S'TJERnHolm [7] has demonstrated this pathway as well as a complete citric acid cycle in peripheral white cells. He observed that the labeled carbon of propionate is incorporated into $\mathrm{CO}_{2}$, citric acid cycle intermediates, aspartate, and glutamate. The latter two amino acids are in equilibrium with two intermediates of the Krebs cycle, i.e., oxaloacetate and $\alpha$-ketoglutarate, respectively.

Control cells, when incubated with ${ }^{14} \mathrm{C}$-propionate, produced labeled succinate and traces of methylmalonate. The presence of radioactivity in $\mathrm{CO}_{2}$, aspartate, and glutamate provided evidence for an intact Krebs cycle. Patient cells, however, accumulated methylmalonate during incubation. The precise nature of the block is unknown.

Tissue biopsies or large numbers of white cells are difficult to obtain from children with genetic defects of propionate metabolism. This difficulty, plus a reluctance to administer radioactive compounds to children, made us look for safer methods of study. Diploid fibroblast cells from skin offer a satisfactory alternative; their physiology is not confused by the disrupted internal milieu of the patient. Tedesco and Mellman [8] have utilized this technique to study and define the metabolic block in a patient with citrullinemia. The cell line developed from the patient with MMA-emia behaves in tissue culture as other human diploid fibroblasts, yet provides cells with the specific biochemical lesion. Although the mutant cell does not require the defective enzyme for normal growth in culture, the defect we have observed is a useful, selective marker in genetic experiments.
References and $\mathcal{N}$ otes

1. Barness, L.A.; Morrow, G.; Kaye, R.; Baker, L. and Drmitrov, N.V.: Methylmalonic aciduria: Metabolic pathways (Abstract). Meeting of the Amer.Pediat.Soc., Atlantic City, New Jersey, May 1-2, 1968.

2. Barness, L.A.; Young, D.; Mellman, W.J.; KaHN, S. B. and Williams, W.J.: Methylmalonate excretion in a patient with pernicious anemia. New Engl.J.Med. 268: 144 (1963).

3. HAyflick, L. and Moorhead, P.S.: The serial cultivation of human diploid cell strains. Exp. Cell Res. 25: 585 (1961).

4. Kaziro, Y. and Ochoa, S.: The metabolism of propionic acid. Adv. Enzymol. 26: 283 (1964).

5. Kesner, L. and Muntwyler, E.: Automatic determination of weak organic acids by partition column chromatography and indicator titration. Anal. Chem. 38: 1164 (1966).

6. Oberholzer, V.G.; Levin, B.; Burgess, E.A. and Young, W.F.: Methylmalonic aciduria-An inborn error of metabolism leading to chronic metabolic acidosis. Arch. Dis. Childh. 42: 492 (1967).

7. Stjernholm, R.L.: Carbohydrate metabolism in leukocytes. VII. Metabolism of glucose, acetate and propionate by human plasma cells. J. Bact. 93: 1657 (1967).

8. Tedesco, T.A. and Mellman, W.J.: Argininosuccinate synthetase activity and citrulline metabolism in cells cultured from a citrullinemic subject. Proc. Nat. Acad.Sci., Wash. 57: 829 (1967).

9. Tedesco, T. and Mellman, W. J.: Desoxyribonucleic acid assay as a measure of cell number in preparations from monolayer cell cultures and blood leucocytes. Exp. Cell Res. 45: 230 (1966).

10. Supported by grants FR-40, HD-00588, HD15545, AM-02231 and Geigy-415.

11. Requests for reprints should be addressed to: G. Morrow, M.D., Hospital of the University of Pennsylvania, 3600 Spruce Street, Philadelphia, Pa. 19104 (USA). 